\title{
EFFECTS OF LIGHT INTENSITY MODIFICATION BY REFLECTIVE ALUMINIZED SCREENHOUSE ON SWEET PEPPER GROWTH AND YIELD
}

\author{
REGIS DE C. FERREIRA ${ }^{1}$, RICARDO DE S. BEZERRA ${ }^{2}$, JULIANO Q. S. ROSA ${ }^{3}$
}

\begin{abstract}
Sweet pepper is one of the ten most consumed vegetables in world. Although it develops better under protected environment, the cultivation in tropical countries is practiced in open field due greenhouse structure higher costs. Unfortunately, such practice has compromised the crop to reach either best yield or fruit quality. Since production and cost are the most important criteria for agricultural production, we aimed to evaluate reflective aluminized polypropylene shading net influence on sweet pepper (Capsicum annuum L.) growth and production as intermediary alternative for low/middle income producers from Brazilian tropical regions. Sweet pepper Magali R hybrid was cultivated in two environments: FC - field conditions (control) and RS - reflective shading net with $40 \%$ shading rate. RS caused reductions in incident solar radiation (SR) and photosynthetically active radiation (PAR) on the amount of $46.3 \%$ and $48.3 \%$, respectively. There were no significant changes in temperature and relative humidity recorded for the two environments. In addition, RS allowed best use efficiency of photosynthetically active radiation since it promoted higher values of plant height, leaf number and area index than those reached on FC on the amount of $29 \%, 22 \%$ and $80 \%$, respectively. Similarly, plants grown under RS showed higher yield and marketable fruits and promoted less loses by sunscald.
\end{abstract}

KEYWORDS: Capsicum annuum L., shading, photosynthetically active radiation, solar radiation use efficiency.

\section{EFEITOS DE MODIFICAÇÕES NA INTENSIDADE LUMINOSA POR TELAS REFLEXIVAS NO CRESCIMENTO E PRODUÇÃO DE PIMENTÕES}

RESUMO: O pimentão figura entre as dez olerícolas mais consumidas em todo o mundo. Embora, ele se desenvolva melhor sob ambiente protegido, seu cultivo, no Brasil, ainda é realizado principalmente sob condições de campo aberto, devido aos altos custos das estruturas fechadas. Infelizmente, tal prática tem comprometido o alcance de melhores rendimento e qualidade dos frutos. Uma vez que a produção e os custos são os critérios mais importantes na produção agrícola, o presente estudo teve como objetivo avaliar a influência de telado de polipropileno aluminizado reflexivo no crescimento e na produção de pimentão (Capsicum annuum L.) como alternativa intermediária para produtores de baixa / média renda das regiões tropicais brasileiras. Pimentão híbrido Magali R foi cultivado em dois ambientes: FC - condições de campo (testemunha) e RS telado reflexivo com $40 \%$ de taxa de sombreamento. A tela reflexiva causou reduções na radiação solar incidente (SR) e na radiação fotossinteticamente ativa (PAR) na ordem de 46,3\% e 48,3\%, respectivamente. Não houve mudanças significativas na temperatura e na umidade relativa do ar registradas para os dois ambientes. O RS permitiu melhor eficiência na utilização da radiação fotossinteticamente ativa, uma vez que promoveu maiores valores de massa por planta, número de folhas e índice de área foliar que em FC na ordem de 29\%, 22\% e 80\%, respectivamente. Da mesma forma, as plantas crescidas sob RS alcançaram maiores rendimento e número de frutos comercializáveis e apresentaram menores perdas por escaldadura.

PALAVRAS-CHAVE: Capsicum annuum L., sombreamento, radiação fotossinteticamente ativa, eficiência do uso da radiação solar.

\footnotetext{
${ }^{1}$ Eng $^{\circ}$ Agrônomo, Prof. Doutor, Escola de Agronomia, Universidade Federal de Goiás/Goiânia-GO, rcastro@ufg.br

${ }^{2}$ Eng $^{\circ}$ Agrônomo, Mestrando, Escola de Agronomia, Universidade Federal de Goiás/Goiânia-GO, rsbezerra.agro@gmail.com

${ }^{3}$ Eng $^{\circ}$ Agrônomo, Doutorando, Escola de Agronomia, Universidade Federal de Goiás/Goiânia-GO, julianoqsr@gmail.com

Recebido pelo Conselho Editorial em: 9-1-2014

Aprovado pelo Conselho Editorial em: 13-3-2014
} 


\section{INTRODUCTION}

Sweet pepper is one of the ten most consumed vegetables worldwide. In Brazil, the cultivated area is estimated around 12,000 ha per year (HENZ et al., 2007). Yield in open area is around 25-40 $\mathrm{t} \mathrm{ha}{ }^{-1}$ and under protected structures reaches $180 \mathrm{t} \mathrm{ha}^{-1}$ in Centre-Southern Brazilian climate conditions (HENZ et al., 2007). It is usually cultivated in open field, but develops better under protected environment (FERREIRA, et al. 2012). Brazilian sweet pepper crops are commonly performed on open field, but they reach higher yield under protected environments. Since this crop develops and produces better under relatively high temperatures or moderate ones, being intolerant to low temperature or frost conditions, sweet pepper demands use of greenhouses, mainly in South and Southeast Brazil (FILGUEIRA, 2008).

The main advantage of protected environment is to produce vegetables in off-season periods, allowing supply regulation and enhanced fruit quality. Excessive solar radiation attenuation and consequent decrease in internal temperature allow certain crops to grown with increased quality, yield and sanity (ILIĆ et al, 2012).

Otherwise, weather changes promoted by protected environments can be adverse, due to excessive internal warming and/or photosynthetically active radiation decrease. Since the solar radiation has decisive importance in all plant vital processes such as photosynthesis, respiration, photoperiod, tissue growth and flowering, among others, a correct choice for protected environment cover material is a crucial issue for plant development (SAPOUNAS et al., 2010). Therefore, spawning suitable weather conditions inside protected environments may be obtained by several techniques, in which the most economical are those that employ use and combination of different types of roofing materials (GUISELINI et al. 2010; LOBOS, et al. 2013).

The reflective shading nets are metalized with aluminium and promote improved energy conservation and solar radiation reflection, resulting in lower summer temperatures and higher winter ones. These nets promote solar radiation diffusion, which increases energy efficiency captured by canopies and improve photosynthesis efficiency (LEITE et al., 2008; KITTAS, et al. 2012).

SANTANA et al. (2012) reached greater yield and higher fruit quality for sweet pepper hybrid grown under photo-selective (red and blue) shading net houses compared with those obtained from open field. According to the authors, losses of commercial fruit by solar blight are significant in open crops.

Thus, this study aimed to evaluate reflective shading net influence on growth, and yield of sweet pepper (Capsicum annuum L.) grown under high energetic density conditions of Brazilian tropical region.

\section{MATERIAL AND METHODS}

\section{Experimental set up}

The experiment was carried out at the College of Agricultural Sciences of Federal University

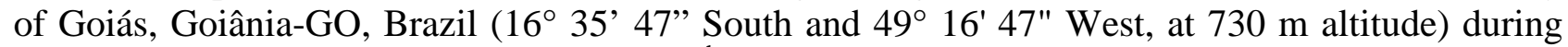
the period of October $01^{\text {st }}$ and December $31^{\text {th }}$ in 2010 . According to Köppen climatic classification, local climate is Aw type, i.e. hot and semi-wet with well-defined dry season between May to September, an average annual temperature of $23.2^{\circ} \mathrm{C}$, and $29.8{ }^{\circ} \mathrm{C}$ and $17.9^{\circ} \mathrm{C}$ as maximum and minimum annual temperature, respectively. Annual rainfall is $1575.9 \mathrm{~mm}$ and total annual sunshine hours is 2588.1 .

Two experimental environment was compared: one using reflexive aluminized shading net (Aluminet $^{\circledR}$, Polysack, Israel) with $40 \%$ shading rate named RS, the structure had $16.0 \mathrm{~m} \mathrm{x} 12.0 \mathrm{x}$ $2.2 \mathrm{~m}$ (length $\mathrm{x}$ width $\mathrm{x}$ height) installed in SW-NE direction; and a second one performed in open area as control (field conditions - FC). 
Sweet pepper seeds (Magali R. hybrid - Sakata Seeds ${ }^{\circledR}$ ) were sown into three 128-cell trays, and filled with commercial substrate composed by pine bark, coconut fiber, peat, charcoal, lime and fertilizer. After sowing, trays were placed inside greenhouse covered with low density polypropylene film. At the $11^{\text {th }}$ day after sowing, seedlings began to emerge and at the $32^{\text {nd }}$ fertilized with 1-L solution per tray containing magnesium sulphate $\left(5.0 \mathrm{~g} \mathrm{~L}^{-1}\right)$, purified MAP (monoammonium phosphate, at $2.5 \mathrm{~g} \mathrm{~L}^{-1}$ ), and potassium sulphate $\left(3.0 \mathrm{~g} \mathrm{~L}^{-1}\right.$ ).

Five beds were prepared (1.0 m width $x 7.0 \mathrm{~m}$ length $\mathrm{x} 0.2 \mathrm{~m}$ height) with $1.0 \mathrm{~m}$ between each other for each environment. Cultivation was performed on double rows and it was used two drip tapes, with $0.3 \mathrm{~m}$ between drippers for irrigation. Black mulching was applied on beds and tracks between beds were covered with pinus dry leaf.

Fertilization was performed according to recommendations of the Commission of Soil Fertility of Goiás, Brazil (EMGOPA, 1988) through application of $60 \mathrm{~m}^{3} \mathrm{ha}^{-1}$ of manure, $1000 \mathrm{~kg}$ $\mathrm{ha}^{-1}$ of 04-30-10 (NPK) commercial formula, $2 \mathrm{~kg} \mathrm{ha}^{-1}$ zinc sulphate and $4 \mathrm{~kg} \mathrm{ha}^{-1}$ borax. Fertilizers were incorporated into soil two weeks prior transplant.

Transplant was performed within $0.5 \mathrm{~m}$ spacing between rows and $0.6 \mathrm{~m}$ between plants in each bed. Each plot had 24 plants arranged in double rows resulting in a population of 17,000 plants per hectare. Plants were grown vertically and on a row, with vertical spacing of $0.2 \mathrm{~m}$ between them. Sprouts below the first bifurcation were eliminated. Fertilization coverage occurred at 30 and 60 days after transplantation with $250 \mathrm{~kg} \mathrm{ha}^{-1}$ of 20-00-20 (NPK) commercial formula.

\section{Meteorological data analysis monitoring}

Meteorological data was monitored through continuous records of solar radiation, photosynthetically active radiation, air temperature and relative humidity by sensors attached to dataloggers (Spectrum ${ }^{\circledR}$, Series 2000). Recorded measures were taken every ten seconds and their average values were calculated every 15 minutes for comparison purposes. The solar radiation (SR) and photosynthetically active radiation (PAR) were obtained from pyranometers and quantum sensors, respectively. All sensors were installed 2 meters above soil surface at center of each environment.

PAR data were recorded in $\mu \mathrm{mol} \mathrm{m} \mathrm{m}^{-2} \mathrm{~s}^{-1}$ and converted into mol $\mathrm{m}^{-2}$ day $^{-1}$ adopting the following procedure (Equation 1):

$$
\text { PAR }=\sum \text { daily } \frac{\operatorname{PAR}\left(\mu m o l m^{-2} s^{-1}\right) x t(s)}{1,000,000}\left(\text { mol of photons } m^{-2} \text { day }^{-1}\right)
$$

For comparison purposes, PAR and SR data were transformed into $\mathrm{MJ} \mathrm{m}^{-2}$ day $^{-1}$ by the equations 2 and 3, respectively (THIMIJAN \& HEINS, 1982).

$$
\begin{aligned}
& \text { PAR }=\sum \text { daily } \frac{\left[\text { PAR }\left(\mu m o l m^{-2} s^{-1}\right) x t(s)\right] / 4.57}{1,000,000}\left(M J m^{-2} \text { day }^{-1}\right) \\
& S R=\sum \text { daily } \frac{\left[S R\left(\mathrm{Wm}^{-2}\right) x t(s)\right]}{1,000,000}\left(M^{-2} m^{-2} \text { day }^{-1}\right)
\end{aligned}
$$

where,

$t$ - the time between samplings, and

4.57 - a conversion factor.

All values from each 15 minutes means were summed.

Vegetative, reproductive and productive traits

Measures were taken weekly from transplant time, in 30 plants for each environment to characterize plant growth, development and yield. Analysed variables were the following: plant height $(\mathrm{cm})$, first bifurcation height $(\mathrm{cm})$, stem diameter $(\mathrm{cm})$, number of leaves and number of flowers per plant, number of fruit per plant, fresh mass (g) per plant. Leaf area (LA) estimation was 
obtained by Equation 4 (PIVETTA et al. 2011) measuring leaf length (L). From estimated LA values, it was determined leaf area index (LAI) (Equation 5).

$$
\begin{aligned}
& L A=0,464 \times L^{1.84} \\
& L A I=\frac{\Sigma L A}{s}
\end{aligned}
$$

where,

$\Sigma_{L A}$ - the sum of areas of all plant leaves $\left(\mathrm{m}^{2}\right)$, and

$S$ - soil area occupied by the plant $\left(0.6 \mathrm{~m}^{2}\right)$.

Statistical analysis

Statistical analyses were performed by comparing independent populations. Each environment was considered a distinct population. Mean comparisons were performed by Student $t$ Test $(\mathrm{p}<0.05)$.

\section{RESULTS AND DISCUSSION}

Meteorological data analysis

Table 1 presents solar radiation, photosynthetically active radiation, temperature and relative humidity averages from the two environments. Photosynthetic photon flux density (PPFD) average in FC and under RS were 977.90 and $516.14 \mu \mathrm{mol} \mathrm{m}^{-2} \mathrm{~s}^{-1}$, respectively. RS attenuated solar radiation and photosynthetically active radiation in $46.3 \%(y=0.5371 x)$ and $48.3 \%(y=0.517 x)$, respectively (Fig. 1a and Fig.1b). FAN et al (2013) reported best results in terms of fresh mass, dry mass, stem diameter, and health under 300, 450 and $550 \mu \mathrm{mol} \mathrm{m}^{-2} \mathrm{~s}^{-1}$ investigating light intensity effects on leaf development for tomato seedlings. According the author, energy efficiency was highest under $300 \mu \mathrm{mol} \mathrm{m}{ }^{-2} \mathrm{~s}^{-1}$ (FAN et al., 2013).

Attenuations in SR and PAR were due to reflection of solar radiation by reflective net, which decreased solar radiation incidence inside the shading net house (GUISELINI et al., 2010). SR attenuation by RS was higher than the commercial specification ( $40 \%$ commercial shading rate). This behaviour can be explained since shading net was not stretched at maximum level, causing a mesh closure and, consequently, greater shading.

TABLE 1. Solar global radiation (SR), photosynthetically active radiation (PAR), relative humidity (RH) in field conditions and under reflective shading net houses (40\% shading), between October $01^{\text {st }}$ and December $31^{\text {th }}$ 2010, Goiânia-GO, Brazil.

\begin{tabular}{lcccc}
\hline \multirow{2}{*}{ Variables } & \multicolumn{2}{c}{ Field Conditions } & \multicolumn{2}{c}{ Reflective Shading net houses } \\
\cline { 2 - 5 } & Average $^{*}$ & CV \%* & Average & CV \% \\
\hline PAR $\left(\mu \mathrm{mol} \mathrm{m}^{-2} \mathrm{~s}^{-1}\right)$ & $507.25 \mathrm{a}$ & 26,19 & $261.82 \mathrm{~b}$ & 27,36 \\
$\mathrm{SR}\left(\mathrm{MJ} \mathrm{m}^{-2} \mathrm{day}^{-1}\right)$ & $23.08 \mathrm{a}$ & 36.17 & $12.37 \mathrm{~b}$ & 26.93 \\
PAR $\left(\mathrm{MJ} \mathrm{m}^{-2} \mathrm{day}^{-1}\right)$ & $9.59 \mathrm{a}$ & 26.19 & $4.95 \mathrm{~b}$ & 27.36 \\
Temp $\left({ }^{\circ} \mathrm{C}\right)$ & $24.57 \mathrm{a}$ & 5.48 & $24.52 \mathrm{a}$ & 5.86 \\
RH $(\%)$ & $78.63 \mathrm{a}$ & 12.21 & $79.85 \mathrm{a}$ & 12.44 \\
\hline
\end{tabular}

*Averages followed by the same letter in row do not differ by t Test (p<P.005). ${ }^{* *}$ Coefficient of variation.

RS did not promote significant changes on temperature and relative humidity during the spring-summer season, even with energy available extenuation. This behaviour suggest that more scattering under this screen compensated shading effects using plastic screen with $50 \%$ shading also found no variations of these meteorological elements in relation to field conditions. This behaviour can be explained by scattering caused by twisted wires of RS (HOCMAN \& SENTELHAS, 2012). KONG et al, (2013) reported no significant difference in air temperature and humidity under pearl and black screen treatments; however, pearl screen increased not only transmittance of long- 
waveband light but also light intensity within plant canopy. According to the authors, pearl screen is more effective in maintaining postharvest sweet pepper fruit quality than traditional black one, especially at late-season harvests, when a more radiation scattering is desirable.

Photosynthetically active radiation in FC was $41.6 \%$ compared to solar radiation (Figure 2a), while in FC, this ratio was $40 \%$ (Figure 2b). Similar behaviour of PAR / SR ratio is explained due to solar radiation reflection by aluminized nets at all wavelengths (MEINHOLD et al. 2010).

SR and PAR behaviours in both environments during completely experimental period are showed in Figure 3. Attenuation caused by RS was $46.3 \%$ and $48.3 \%$, respectively to SR and PAR. This behaviour maintains unchanged PAR and infrared (IR) radiation ratios and only changes the amount of available energy that reach surfaces inside the protected environment (GUISELINI, et al., 2010).

\section{Vegetative, reproductive and productive traits}

Table 2 presents average values of phenological variables for both environments. Plant height was 29\% higher under RS, differing statistically with those on field conditions. Likewise, leaf number was 22\% higher under RS, which, consequently, contributed to higher plant heights. Average steam diameter and flower number did not differ significantly between environments. Thus, showing that the amount of incident energy on canopies under reflective shading net was not sufficient to cause influence on those parameters, but influenced number of leaves.

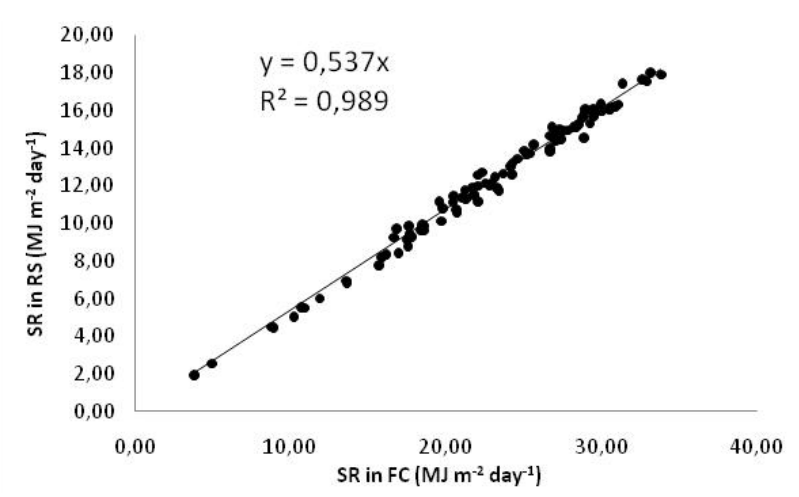

(a)

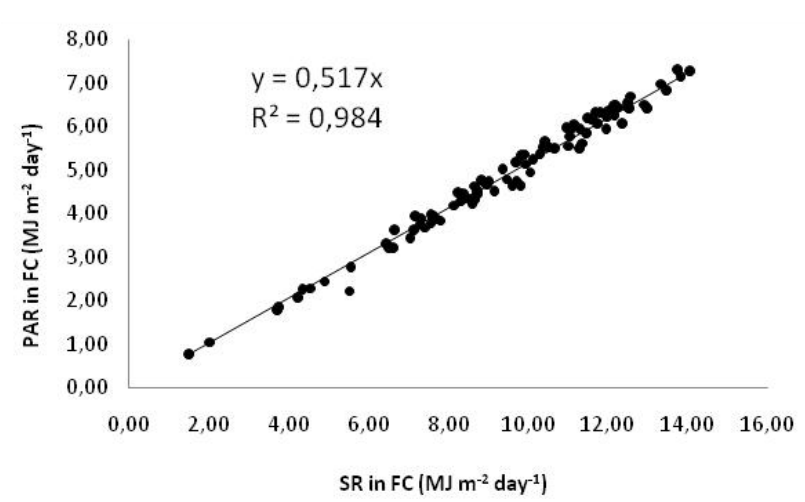

(b)

FIGURE 1. Relationship between solar radiation in field conditions (SR, in FC) and solar radiation under reflective shading net (SR, under RS) (a); and relationship between photosynthetically active radiation in field conditions (PAR, in FC) and photosynthetically active radiation under reflective shading net (PAR, under RS) (b) between October $01^{\text {st }}$ and December $31^{\text {th }}$ 2010, Goiânia-GO, Brazil.

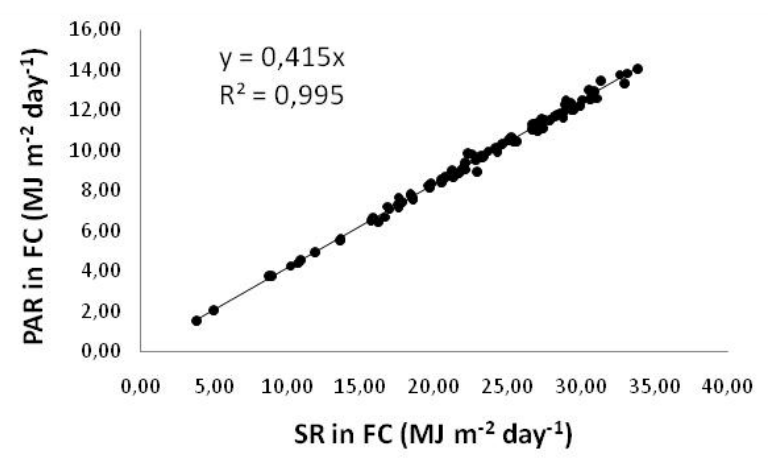

(a)

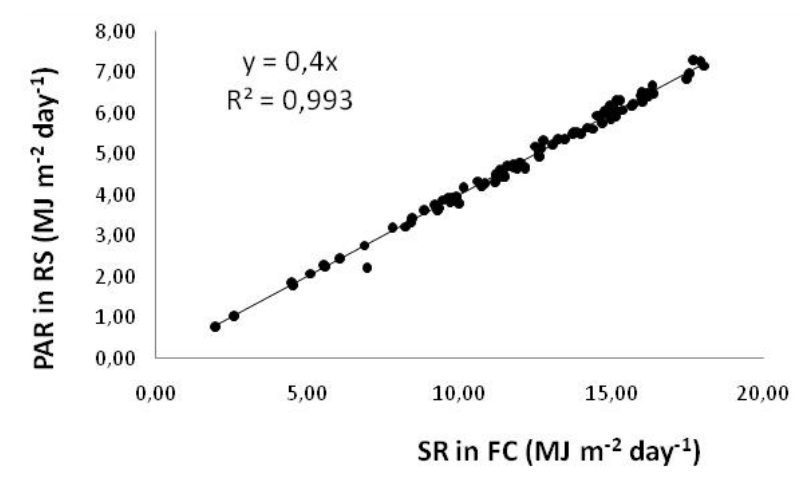

(b)

FIGURE 2. Relationship between global solar radiation (SR) and photosynthetically active radiation (PAR) in field conditions (FC) (a) and under reflective shading net (RS) (b) between October $01^{\text {st }}$ and December $31^{\text {th }}$ 2010, Goiânia-GO, Brazil. 


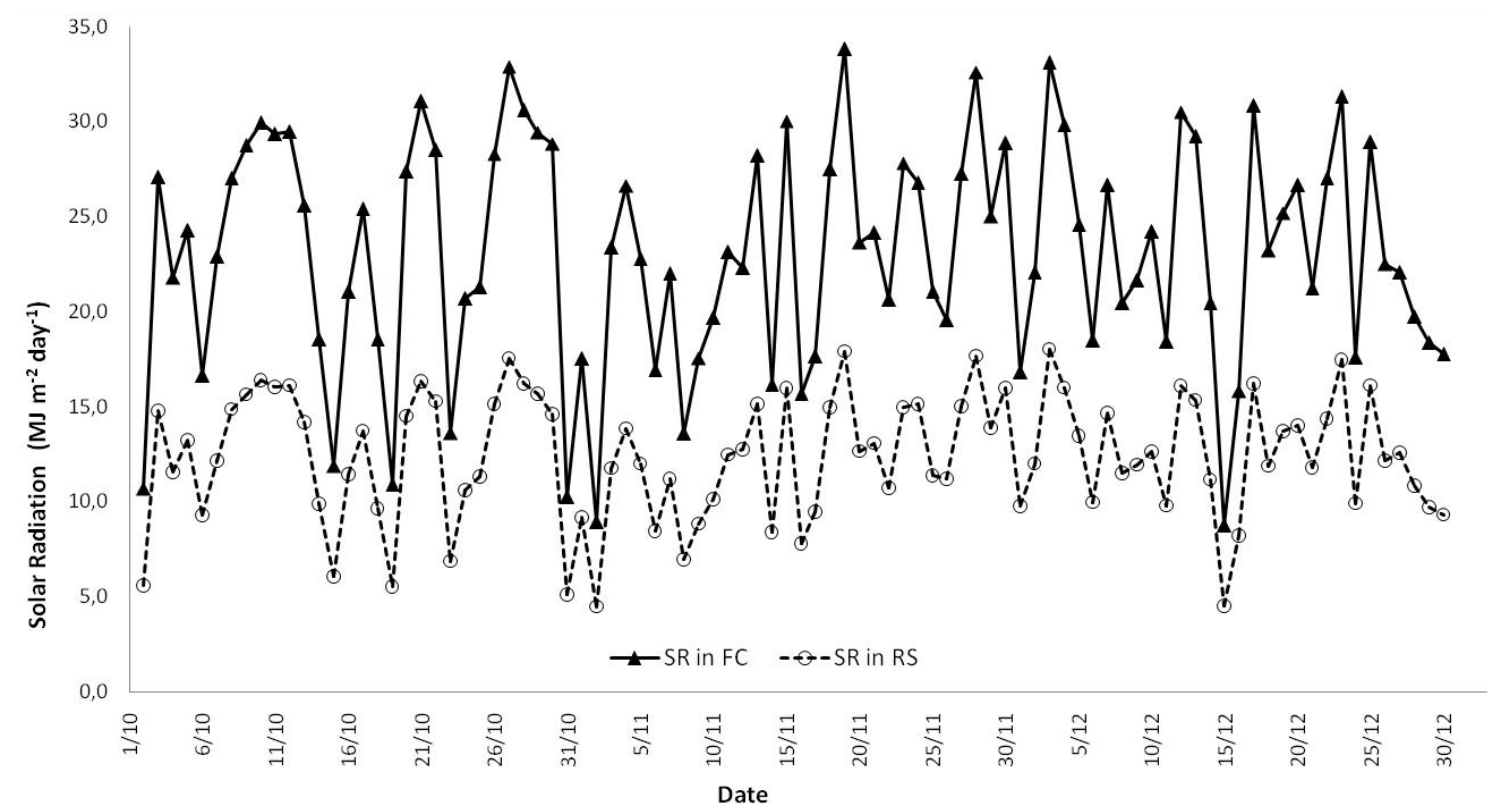

(a)

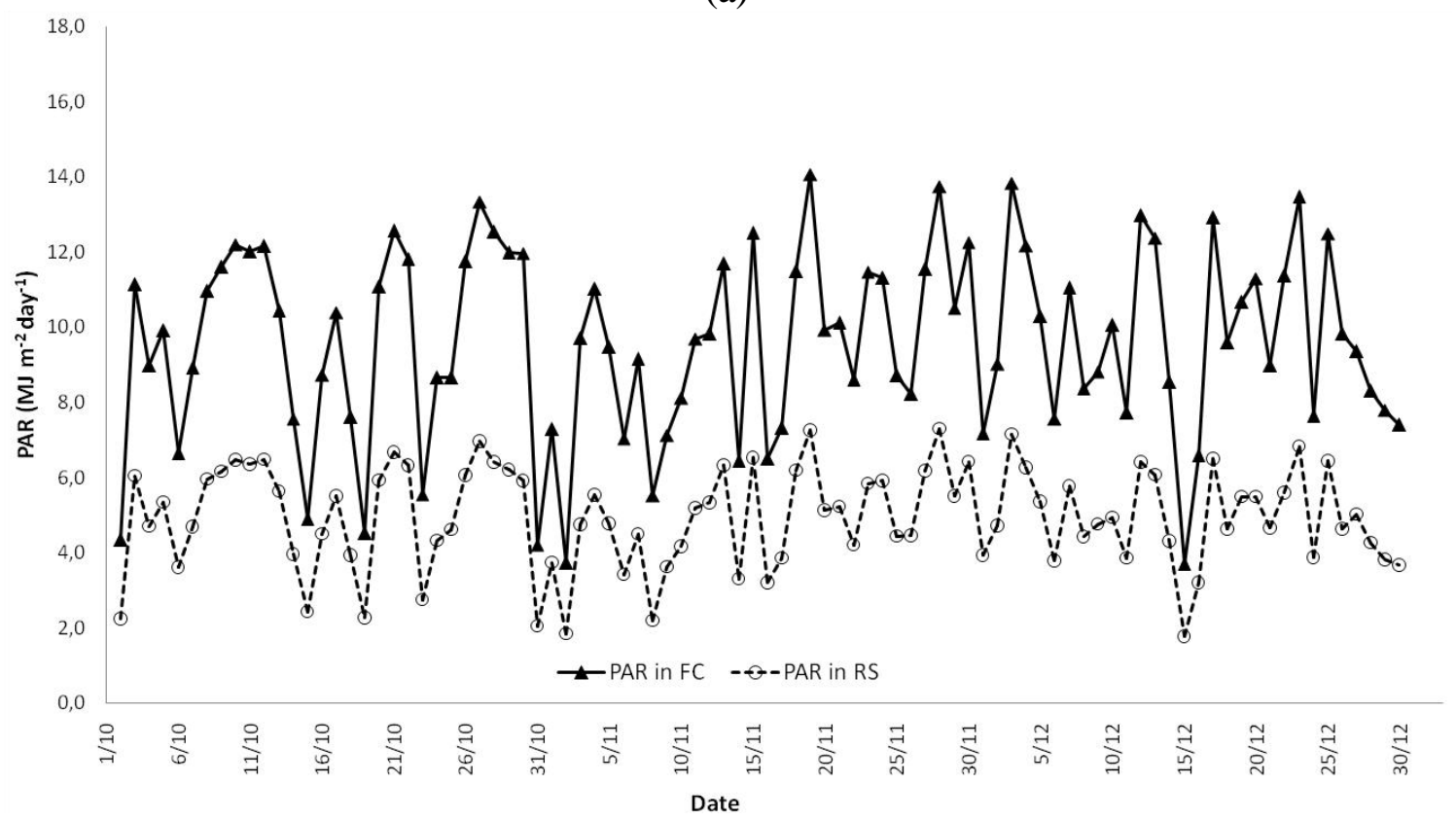

(b)

FIGURE 3. Behaviour of Solar radiation (SR) (a) and photosynthetically active radiation (PAR) (b) in field conditions (FC) and under reflective shading net (RS) during October $01^{\text {st }}$ and December $31^{\text {th }}$ 2010, Goiânia-GO, Brazil.

Considering SR and PAR have been the unique weather element unchanged from those reported in field conditions, a higher number of leaves under RS environment was influenced by PAR attenuation. GUISELINI et al. (2010), evaluating thermal reflective net effect on Gerbera jamesonii production, reported that differences on leaf area and flower bud number were due to solar radiation reduction by shading.

Likewise, Table 3 shows that leaf area index differed significantly between environments. On average, LAI under RS was 80\% higher than in plants grown in FC (Figure 4). COSTA et al. (2010) reported $60 \%$ more fresh biomass accumulation in seedlings of passion fruit under reflective shading net (50\% shading) comparing with greenhouse without shading. SANTOS et al. (2011) found 56\% higher shoot dry mass on seedlings of Hymenaea stigonocarpa Mart. than in a greenhouse covered with light diffuser polyethylene film associated with reflective screen (50\% 
shading) to those found under black screens (50 \% shading). This behaviour highlights the increase in number and size of leaves is mechanisms that plants use in order to compensate the PAR attenuation in shading conditions.

Table 4 presents average values of yield variables. RS promoted higher values of fruit number and fresh fruit mass per plant comparing to FC. From results, we can estimate a yield of $18800 \mathrm{~kg}$ $\mathrm{ha}^{-1}$ under RS comparing to $15,800 \mathrm{~kg} \mathrm{ha}^{-1}$ for FC, i.e., $16 \%$ higher.

Despite higher attenuation of PAR, yield results reveal indirectly a better efficiency of available energy use under RS. Similarly, MEDINA et. al. (2002) reported that photosynthetic performance of citrus cultivated in greenhouses can be improved using reflective nets, which reduces incident PAR and leaf temperatures. Favourable effects of these microclimate alterations comprises not only maintenance of proper stomatal aperture for gas exchange but also a better functioning of photochemical system under that non-photoinhibitory conditions (MEDINA et. al., 2002).

Equally, fruit harvested from RS showed greater sanity and better visual appearance (Figure 5). COSTA et al. (2011) reported no significant differences on fruit production of strawberry marketable fruits produced under LPDE greenhouses associated to reflective nets; they also report a better visual quality and nutritional value for fruit.

TABLE 2. Plant height $(\mathrm{cm})$, steam diameter $(\mathrm{cm})$, flower number and leaf number at field conditions and under reflective shading net. Goiânia-GO, Brazil, 20130.

\begin{tabular}{lcccccccc}
\hline & \multicolumn{2}{c}{ Plants height $(\mathrm{cm})$} & \multicolumn{2}{c}{ Steam diameter $(\mathrm{cm})$} & \multicolumn{2}{c}{ Flower number } & \multicolumn{2}{c}{ Leaf Number } \\
\cline { 2 - 9 } Date & $\begin{array}{c}\text { Field } \\
\text { Conditions }\end{array}$ & $\begin{array}{c}\text { Reflective } \\
\text { shading net }\end{array}$ & $\begin{array}{c}\text { Field } \\
\text { Conditions }\end{array}$ & $\begin{array}{c}\text { Reflective } \\
\text { shading net }\end{array}$ & $\begin{array}{c}\text { Field } \\
\text { Conditions }\end{array}$ & $\begin{array}{c}\text { Reflective } \\
\text { shading net }\end{array}$ & $\begin{array}{c}\text { Field } \\
\text { Conditions }\end{array}$ & $\begin{array}{c}\text { Reflective } \\
\text { shading net }\end{array}$ \\
\hline Oct/ 8 & $10.7 \mathrm{a}^{*}$ & $12.4 \mathrm{~b}$ & $0.2 \mathrm{a}$ & $0.2 \mathrm{a}$ & - & - & $6.1 \mathrm{a}$ & $6.4 \mathrm{a}$ \\
Oct/ 15 & $13.0 \mathrm{a}$ & $14.9 \mathrm{~b}$ & $0.3 \mathrm{a}$ & $0.3 \mathrm{a}$ & - & - & $7.3 \mathrm{a}$ & $9.3 \mathrm{~b}$ \\
Oct/ 22 & $17.7 \mathrm{a}$ & $22.4 \mathrm{~b}$ & $0.4 \mathrm{a}$ & $0.4 \mathrm{a}$ & - & - & $11.5 \mathrm{a}$ & $13.8 \mathrm{~b}$ \\
Oct/ 29 & $23.6 \mathrm{a}$ & $33.1 \mathrm{~b}$ & $0.5 \mathrm{a}$ & $0.6 \mathrm{a}$ & - & - & $17.2 \mathrm{a}$ & $23.5 \mathrm{~b}$ \\
Nov/ 5 & $33.3 \mathrm{a}$ & $45.6 \mathrm{~b}$ & $0.6 \mathrm{a}$ & $0.7 \mathrm{a}$ & - & - & $25.5 \mathrm{a}$ & $34.8 \mathrm{~b}$ \\
Nov/ 12 & $43.1 \mathrm{a}$ & $58.9 \mathrm{~b}$ & $0.9 \mathrm{a}$ & $1.0 \mathrm{a}$ & $2.1 \mathrm{a}$ & $2.5 \mathrm{a}$ & $38.7 \mathrm{a}$ & $55.5 \mathrm{~b}$ \\
Nov/ 19 & $51.1 \mathrm{a}$ & $72.5 \mathrm{~b}$ & $1.2 \mathrm{a}$ & $1.2 \mathrm{a}$ & $2.8 \mathrm{a}$ & $4.4 \mathrm{~b}$ & $53.0 \mathrm{a}$ & $78.3 \mathrm{~b}$ \\
Dec/ 3 & $60.2 \mathrm{a}$ & $88.0 \mathrm{~b}$ & $1.6 \mathrm{a}$ & $1.5 \mathrm{a}$ & $2.6 \mathrm{a}$ & $2.2 \mathrm{a}$ & $102.1 \mathrm{a}$ & $120.5 \mathrm{~b}$ \\
Dec/ 17 & $61.2 \mathrm{a}$ & $93.2 \mathrm{~b}$ & $1.7 \mathrm{a}$ & $1.6 \mathrm{a}$ & $1.2 \mathrm{a}$ & $1.8 \mathrm{a}$ & $123.4 \mathrm{a}$ & $151.9 \mathrm{~b}$ \\
\hline
\end{tabular}

*Averages followed by the same letter in row do not differ by t Test $(\mathrm{p}<0.05)$.

TABLE 3. Evolution of leaf area index for field conditions and reflective shading net.

\begin{tabular}{lcccc}
\hline \multirow{2}{*}{ Date } & \multicolumn{2}{c}{ Field Conditions } & \multicolumn{2}{c}{ Reflective shading net } \\
\cline { 2 - 5 } & Average $^{*}$ & CV (\%) & Average & CV (\%) \\
\hline Oct/ 15 & $0.014 \mathrm{a}$ & 31.4 & $0.023 \mathrm{~b}$ & 30.7 \\
Oct/ 22 & $0.027 \mathrm{a}$ & 42.1 & $0.054 \mathrm{~b}$ & 32.4 \\
Oct/ 29 & $0.054 \mathrm{a}$ & 48.6 & $0.115 \mathrm{~b}$ & 34.3 \\
Nov/ 5 & $0.093 \mathrm{a}$ & 30.9 & $0.189 \mathrm{~b}$ & 36.4 \\
Nov/ 12 & $0.168 \mathrm{a}$ & 25.2 & $0.312 \mathrm{~b}$ & 30.0 \\
Nov/ 26 & $0.474 \mathrm{a}$ & 59.6 & $0.691 \mathrm{~b}$ & 27.2 \\
Dec/ 10 & $0.483 \mathrm{a}$ & 29.9 & $0.969 \mathrm{~b}$ & 31.8 \\
\hline
\end{tabular}

*Averages followed by the same letter on the row do not differ by the t Test $(\mathrm{p}<0.05)$. ** Coefficient of variation. 


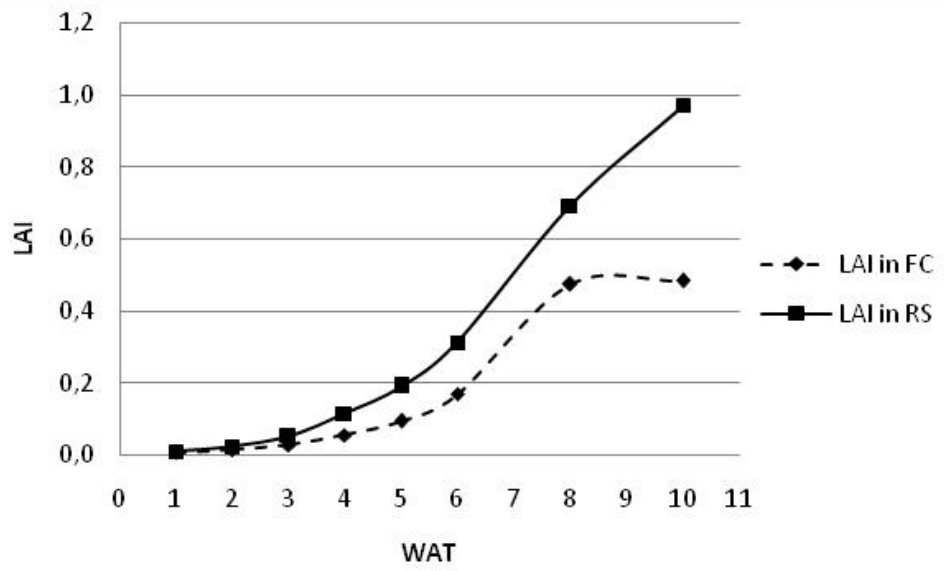

FIGURE 4. Leaf area index (LAI) in function of week after transplanting (WAT) for plants grown at field conditions (FC) and under the reflective shading net (RS).

TABLE 4. Fruit number per plant and total fresh mass of fruit harvested per plant and their coefficient of variation (CV) at field conditions and under reflective shading net.

\begin{tabular}{lcccc}
\hline \multirow{2}{*}{ Variables per plant } & \multicolumn{2}{c}{ Field Conditions } & \multicolumn{2}{c}{ Reflective shading net } \\
\cline { 2 - 5 } & Average & CV (\%) & Average & CV (\%) \\
\hline Number of fruits & $7.7 \mathrm{~b}^{*}$ & 33.62 & $8.87 \mathrm{a}$ & 29.13 \\
Fresh mass (g) & $978.87 \mathrm{~b}$ & 37.91 & $1125.80 \mathrm{a}$ & 31.73 \\
\hline
\end{tabular}

*Averages followed by the same letter in row do not differ by t Test $(\mathrm{p}<0.05)$. ${ }^{* *}$ Coefficient of variation.

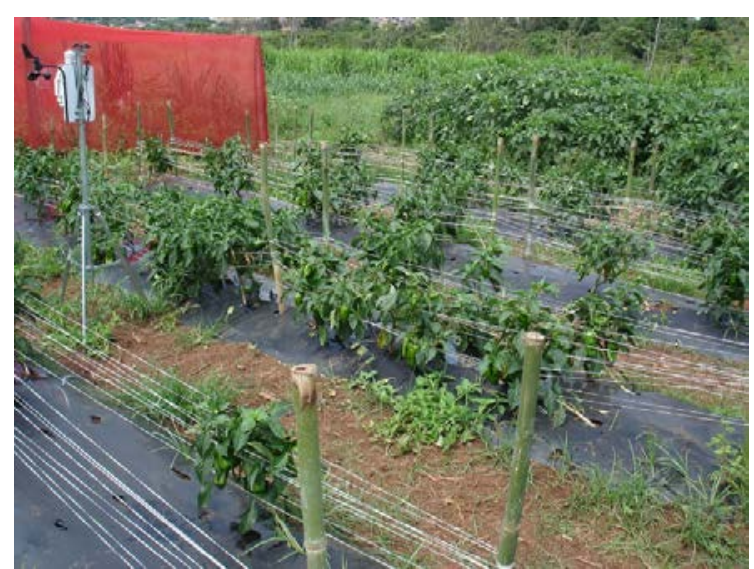

(a)

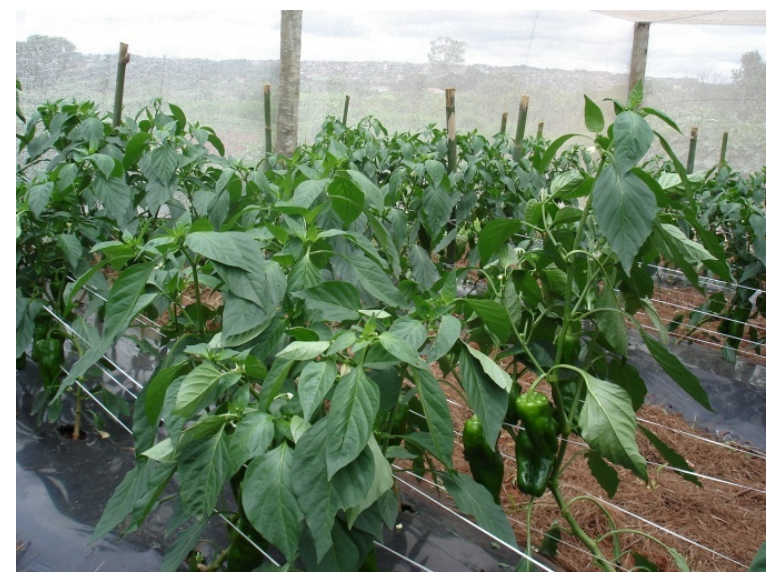

(c)

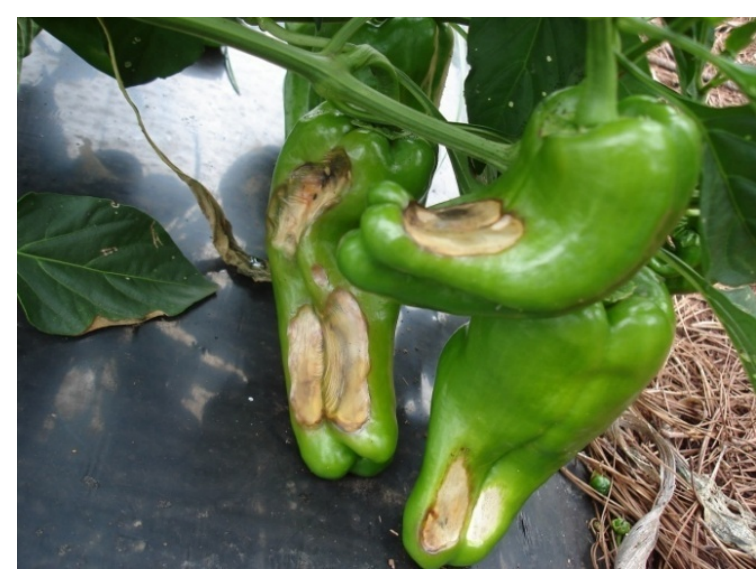

(b)

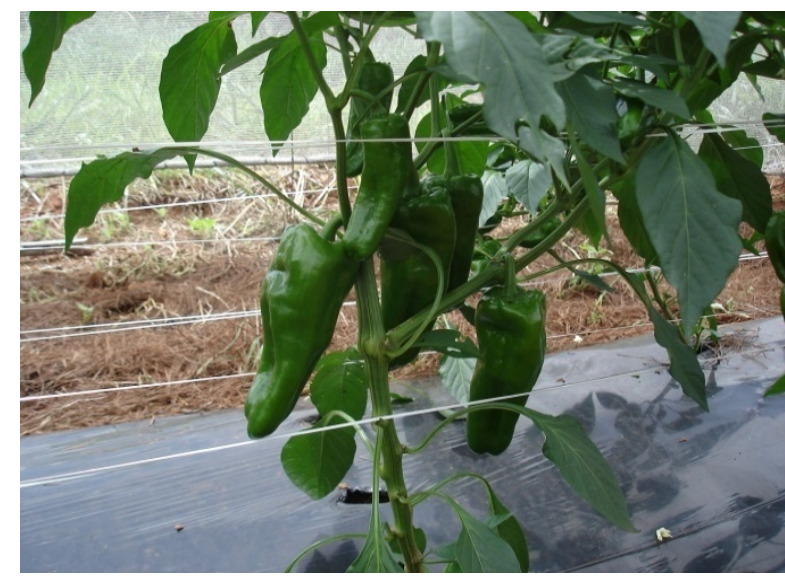

(d)

FIGURE 5. General view of plant stand and sanity aspect of pepper fruit at field conditions (a and b), and under reflective shading net (c and d). 


\section{CONCLUSIONS}

Reflective aluminized shading net (40\% shading) reduces photosynthetically active radiation incidence in $48.8 \%$, and does not change both internal temperature and relative humidity for the spring-summer season in Brazilian tropical region.

Photosynthetically active radiation attenuation by reflective shading net alters phenological characteristics of sweet peppers in terms of leaf number and leaf area index.

Reflective shading net does not affect yield of sweet pepper grown during the spring-summer season (rainy) in Brazilian tropical region and contributes to fruit production with enhanced quality and lower incidence of disease problems.

\section{ACKNOWLEDGMENTS}

We want to thank the Foundation for Research Support of the State of Goiás, Brazil (FAPEG) by financial support to perform this study. Second and the third authors thank, respectively, the Brazilian Coordination of Higher Education Personnel (CAPES) and the National Council for Scientific and Technological Development (CNPq) for granted scholarship.

\section{REFERENCES}

COHEN, S.; RAVEH, E.; LI, Y.; GRAVA, A.; Goldschmidt, E.E. Physiological responses of leaves, tree growth and fruit yield of grapefruit trees under reflective shade screens, Scientia Horticulturae, Amsterdam, v.107, n.1, p.25-35, 2005.

COMISSÃO DE FERTILIDADE E SOLOS DE GOIÁS. Recomendações de corretivos e fertilizantes para Goiás: 5a. Aproximação. Goiânia: UFG: EMGOPA, 1988. 101 p. (Informativo técnico, 1).

COSTA, E; LEAL, P. A. M.; SASSAQUI, A. R.; GOMES, V. A. G. Doses de composto orgânico comercial na composição de substratos para a produção de mudas de maracujazeiro. Engenharia Agrícola, Jaboticabal, v.30, n.5, p.776-787, 2010.

COSTA, R. C.; CALVETE, E. O.; REGINATTO, F. H.; RAMBO, A.; LOSS, J. T.; BORDIGNON JÚNIOR, C. Telas de sombreamento na produção de morangueiro em ambiente protegido. Horticultura Brasileira, Brasilia, v. 29, p. 98-102, 2011.

FAN, X.; XU, X.; LIU, X.; TANG, C. WANG, L.; HAN, X. Effects of light intensity on the growth and leaf development of young tomato plants grown under a combination of red and blue light. Scientia Horticulturae, Amsterdam, v. 153, n. 4, p.50-55, 2013.

FERREIRA, T.A.P.C., VALADARES, K.O., SOUZA, M.J.F., SANTANA, J.Q., BALBINO, M.P. AND FERREIRA, R.C. Yellow and red sweet pepper quality under photoselective screens and field crop conditions. Acta Horticulturae, The Hague, v. 956, p.473-479, 2012.

FILGUEIRA, F. A. R. Novo manual de olericultura: agrotecnologia moderna na produção e comercialização de hortaliças. 3. ed. Viçosa: UFV, 2008. 412p.

GUISELINI, C.; SENTELHAS, P.C.; PANDORFI, H.; HOLCMAN, E. Manejo da cobertura de ambientes protegidos: radiação solar e seus efeitos na produção da gérbera. Revista Brasileira de Engenharia Agrícola e Ambiental, Campina Grande, v. 14, n. 6, 2010.

HENZ, G.P.; COSTA, S.R.; CARVALHO, S. Como cultivar pimentão. Cultivar Hortaliças e Frutas, Pelotas, n. 42, fev./mar. 2007.

HOLCMAN, E. ; SENTELHAS, P.C. Microclima sob diferentes malhas de sombreamento em ambiente protegido cultivado com bromélias. Revista Brasileira de Engenharia Agrícola e Ambiental, Campina Grande, v. 16, p. 858-863, 2012. 
ILIĆ, Z. S.; MILENKOVIĆ, L.; STANOJEVIĆ, L.; CVETKOVIĆ, D., FALLIK, E. Effects of the modification of light intensity by color shade nets on yield and quality of tomato fruits, Scientia Horticulturae, Amsterdam, v.139, p. 90-95, 2012.

LEITE, C.A.; ITO, R.M.; LEE, G.T.S.; GANELEVIN, R.; FAGNANI, M.A. Light spectrum management using colored nets to control the growth and blooming of phalaenopsis. Acta Horticulture, The Hague, v. 770, p. 177-184, 2008.

LOBOS, G.A.; RETAMALES, J.B.; HANCOCK, J.F.; FLORE, J.A.; ROMERO-BRAVO, S.; DEL POZO, A. Productivity and fruit quality of Vaccinium corymbosum cv. Elliott under photo-selective shading nets, Scientia Horticulturae, Amsterdam, v.153, n.4 p.143-149, 2013.

MEDINA, C. L., SOUZA, R. P., MACHADO, E. C. RIBEIRO, R. V., SILVA, J. A. B. Photosynthetic response of citrus grown under reflective aluminized polypropylene shading nets, Scientia Horticulturae, v. 96. n.6, p.115-125, 2002.

KITTAS, C., KATSOULAS, N., RIGAKIS, N., BARTZANAS, T., KITTA, E. Effects on microclimate, crop production and quality of a tomato crop grown under shade nets. Journal of Horticultural, Science \& Biotechnology, Ashford, v. 87, n.1, p.7-12, 2012.

KONG, Y.; AVRAHAM, L.; PERZELAN, Y.; ALKALAI-TUVIA, S.; RATNER, K., SHAHAK, Y.; FALLIK, E. Pearl netting affects postharvest fruit quality in 'Vergasa' sweet pepper via light environment manipulation, Scientia Horticulturae, Amsterdam,v.150, n.4, p.290-298, 2013.

MEINHOLD, T., DAMEROW, L. BLANKE, M. Reflective materials under hailnet improve orchard light utilisation, fruit quality and particularly fruit colouration, Scientia Horticulturae, Amsterdam, v.127, n. 3,p.447-451, 2010.

PIVETTA, C. R.; HELDWEIN, A. B.; MALDANER, I.; RADONS, S.; TAZZO, I. LUCAS, D. D. Evapotranspiração máxima do pimentão cultivado em estufa plástica em função de variáveis fenométricas e meteorológicas. Revista Brasileira de Engenharia. Agrícola e Ambiental, Campina Grande, v.14, n.7, p.768-775, 2010.

SAPOUNAS, A. A.; HEMMING, S.; DE ZWART, H. F.; CAMPEN, J. B. Influence of insect nets and thermal screens on climate conditions of commercial scale greenhouses: a CFD approach. In: CONGRESS OF THE INTERNATIONAL COMMISSION OF AGRICULTURAL AND BIOSYSTEMS ENGINEERING, 17., 2010, Québec. Proceedings...

SANTANA, J.Q., BALBINO, M.A., TAVARES, T.R., BEZERRA, R.S., FARIAS , J.G. AND FERREIRA, R.C. Effect of photoselective screens in the development and productivity of red and yellow sweet pepper. Acta Horticulturae, The Hague, v.956, p.493-500, 2012.

SANTOS, L. C. R.; COSTA, E.; LEAL, P. A. M.; NARDELLI, E. M. V.; SOUZA, G. S. A. S. Ambientes protegidos e substratos com doses de composto orgânico comercial e solo na formação de mudas de jatobazeiro em Aquidauana-MS. Engenharia Agrícola, Jaboticabal, v.31, n.2, p.249259, 2011.

THIMIJAN, R. W.; ROYAL, D. HEINS. Photometric, Radiometric, and Quantum Light Units of Measure: A Review of Procedures for Interconversion. HortScience, Alexandria, v. 18, p.818-822, 1982. 